\title{
THE MEDICINE ROUND
}

\section{TERESA JAFTHA \\ Groote Schuur Hospital}

\section{Senior Professional Nurse, Clinical Teaching Department}

I am working on a research project for the hospital and so I had to come on night duty to accompany the senior nurse on the medicine round.

I don't really know what hit me, but suddenly I saw the ward through real eyes. I plead guilty as well, because on many occasions I uttered the words the situation is critical and I understand. I did not really, not until last night.

Forty-four very ill patients in need of care, constant care, physical and emotional, crying out verbally and non-verbally:

I'm scared

I'm in pain

I'm dying - help me!

I'm uncomfortable

I feel that these tablets are not working

I need a relative

I need a hug

My mouth is dry - water

I need a turn

My IVAC is making a noise something's wrong

My drip is almost empty

Rub my back

I need a bedpan

I feel as if I'm slipping away

Just stay for a while nurse - I'm terrified

I'm cold

I'm wet

I then observed, through these same real eyes, or new insight, four girls in white uniforms. Now whis- pering, now moving briskly, then fast to attend to the needs of their patients, with warmth, love and understanding.

From time to time they would approach their leader, a three striper, give feedback or ask advice. She, the leader, was organising with her mind, her hands, supporting her team with effort and courage.

Now she was ready for the medicine round. She knew what she was doing, oh yes, she picked up, and saw what I saw. In each and every patient - other needs - - things that could be done to make it easier or more comfortable, she could not ... She verbalised very gingerly from time to time, this patient is not so well, that patient is dying, I'm helpless, but this great task, administration of their medicines, must be done - and besides this great task, I am now alone with 20 sick male patients, because one of $m y$ nurses is in the unit with three very sick renal patients, the one, very depressed, and on dialysis too. She's coping, that nurse, and from time to time she will come and offer an extra hand in the ward.

The other two nurses are in the female ward, attending to their needs, changing them, recording their vital signs, blood pressures, urinalysis, bedpans, checking drips, lifting and making them comfortable, consoling and reassuring.

So I must carry on, some patients on seven and eight or more medica- tions, some too sick to lift their heads, they need assistance. She must make sure that they swallow their tablets - they hesitate, they are ill, tired, they take their time.

Maybe if they take longer they will have more of her than what she can offer at present.

And so it went, from bed to bed patient to patient - just saying good evening, how are you? then your medication. Then maybe a lift here and there. Then checking drips, resetting an IVAC, running to get a bedpan and bottle.

Then there is the phone. She has to answer calls to worried relatives outside. Yes, they want good explanations, and this takes time.

After two hours, she completed her medicine round. She still smiled. Now the Schedule 5 medications, she said, at present there are seven. Sometimes, she said, sometimes, when we are very busy, it is double, or more. I thought she said busy! Well what is this then to her?

I felt like just hugging her - so much strength - so much love.

At $11.10 \mathrm{pm}$ they walked into the office, shyly, and so very humble. They pour some tea, maybe eat a sandwich.

The lights are out now. They prepare themselves for a long, long, busy night. I was humbly moved. 